individualnost, izbiro hitrosti učenja, raven dosežkov in tudi individualno delo učiteljev, prilagojeno potrebam udeležencev.

$\mathrm{Z}$ nami sodeluje vec kot 200 stalnih zunanjih sodelavcev, $\mathrm{ki}$ imajo znanje, elan in nove ideje. Prav njim gre velika zasluga za uspešno izvajanje programov.

$\mathrm{V}$ petih letih delovanja se je naših programov (tečaji, seminarji, delavnice) udeležilo več kot 13.000 udeležencev (otrok in odraslih). Pripravili smo več kot 80 različnih programov in 66.000 izobraževalnih ur.

Uspešni smo bili tudi zato, ker smo za nove projekte našli podporo pri ministrstvu za šolstvo, ministrstvu za delo, republiškem zavodu za zaposlovanje, mariborskem zavodu za zaposlovanje in andragoškem centru. Hvala vsem s prepričanjem, da bo tako tudi v prihodnje, in $z$ upanjem, da se bodo naši dejavnosti tudi na mariborski mestni občini začela odpirati vrata.

V Dobi bomo naredili vse, da bi posameznikom pomagali odpreti oči, da se bodo zavedali svojih možnosti in sposobnosti ter se razvijali tako, da se bo tudi naše mesto sposobno dinamično razvijati in kvalitetno rasti ne samo v gospodarstvu, temveč tudi v mišljenju, izobraževanju in komunikaciji. V Mariboru želimo dati prednost razvijanju znanja in sposobnosti pri prebivalcih vseh starosti. V tem prizadevanju bi zelo pomagalo, ce bi si postavili ideal »učečega se mesta«.

Z veseljem lahko povem, da v Mariboru s pomočjo Ministrstva za ふolstvo in šport ustanavljamo Središce za spodbujanje učenja, ki je za naše mesto še kako pomembno in pomeni prvi korak $\mathrm{k}$ temu idealu.

\title{
Tradicionalni salzburški pogovori ○ izobraževanju odraslih
}

Anita Kalpan

V Salzburgu so bili od 16. do 22. julija letos osemintrideseti salzburški pogovori o izobraževanju odraslih $\mathrm{v}$ organizaciji Zveze avstrijskih ljudskih univerz (Verband Österreichischer Volkshochschule) in pod pokroviteljstvom Evropskega urada za izobraževanje odraslih (Europäisches Buro für Erwachsenenbildung). Letošnji pogovori so bili posvečeni izredno zanimivi temi -izobraževanju odraslih kot državljanskemu gibanju. Navzoči so bili znanstveniki in strokovnjaki (skupaj 60 udeležencev) iz več evropskih držav (Avstrije, Nemčije, Belgije, Švice, Madžarske, Češke, Slovaß̌ke, Bolgarije, Slovenije, Hrvaške, Poljske, Ukrajine... pa tudi iz Japonske in Sierre Leone). V okviru napovedane teme so poleg drugega razpravljali o naslednjih interdisciplinarnih vprašanjih: Ali izobraževanje odraslih lahko poskrbi za potrebe in interese državljanov? Kako lahko izobraževanje odraslih postane podpora interakcijskim družbenim procesom in vpliva na to, da državljani postanejo bolj gibljivi in dejavni? Je lahko izobraževanje odraslih $\mathrm{v}$ zvezi s tem osnova za javno razpravo? Katere metode, načela in modeli izobraževanja odraslih so učinkoviti v procesih družbene in državljanske gibljivosti in demokratizacije družbe.

Salzburški pogovori so potekali plenamo in po skupinah. Uvodno predavanje je imel prof. dr. Johan Kade iz Nemčije, potem pa je delo potekalo $v$ treh delovnih skupinah. Na koncu je bila opravljena sinteza rezultatov dela skupin, dogovorjene pa so bile možne vsebine za prihodnje pogovore. Pripomnimo lahko še to, da je izmenjava izkušenj in spoznanj na letošnjih salzburških pogovorih potekala $v$ znamenju kritičnega vendar zelo strpnega ozraçja, kot se spodobi za prireditev $s$ takšno tradicijo in udeleženci.

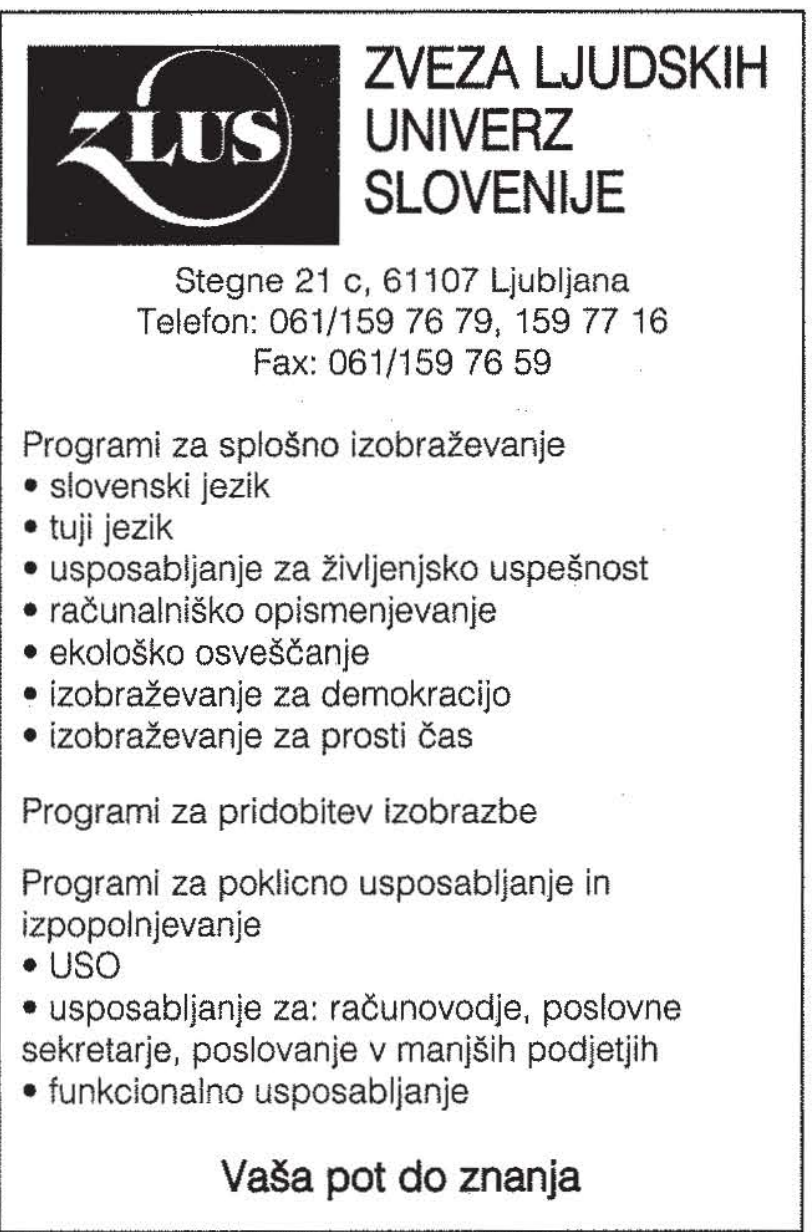

